\title{
ОЦЕНКА СОРТООБРАЗЦОВ РЫЖИКА ОЗИМОГО (Camelina sylvestris Waller ssp. pilosa Zing.) ПО ЭКОЛОГИЧЕСКОЙ АДАПТИВНОСТИ
}

\author{
Е.Л. ТУРИНА', Т.Я. ПРАХОВА², Е.Н. ТУРИН', А.А. ЗУБОЧЕНКО1, \\ B.A. ПРАХОВ 2
}

Рыжик озимый (Camelina sylvestris Waller ssp. pilosa Zing.) - масличная культура, которая становится все более востребованной благодаря высокой масличности и широким возможностям использования. С экологической точки зрения рыжик озимый - довольно пластичное растение, поскольку легко приспосабливается к различным почвенно-климатическим условиям. Рыжик характеризуется холодостойкостью и засухоустойчивостью. Увеличение посевных площадей рыжика озимого и его продуктивности зависит от генетического разнообразия сортов, адаптированных к условиям региона возделывания, а также от взаимодействия генотип-среда. В представленной работе на основании результатов многолетних исследований впервые установлено, что в условиях Среднего Поволжья и степного Крыма сортообразцы озимого рыжика характеризуются адаптивностью, стабильностью и способностью формировать высокий и качественный урожай. Это позволяет использовать их для селекции новых сортов, адаптированных к возделыванию в обоих регионах. Цель работы - оценка сортообразцов озимого рыжика по экологической адаптивности и стабильности в двух контрастных агроэкологических регионах. Исследования проводили в 20152017 годах в Среднем Поволжье (Пензенский НИИ сельского хозяйства, р.п. Лунино, Пензенская обл.) и степном Крыму (НИИ сельского хозяйства Крыма, с. Клепинино, Красногвардейский р-н) на сортах Пензяк, Козырь, Барон и сортообразцах Дикий, и.о.-4172, и.о.-1357, и.0.-2219, и.о.4155, и.о.-4164, и.о.-4156, и.0.-4175, и.0.-3290 и и.0.-4165 рыжика озимого различного экологогеографического происхождения. Стандартом служил сорт Пензяк (селекция Пензенского НИИ сельского хозяйства). Возделывание рыжика в севообороте, закладка полевых опытов, наблюдения и учеты осуществлялись по рекомендациям для масличных культур. Посев проводили в оптимальные для конкретного региона сроки рядовым способом с междурядьями 15 см и нормой высева семян 8,0 млн шт/га. Зимостойкость оценивали на основании данных осеннего и весеннего учетов состояния посевов в каждом повторении по обеим зонам. Урожайность определяли методом пробных площадок (1 м²). Параметры экологической стабильности и адаптивности (bi) определяли на основании коэффициента регрессии. Реализацию потенциала урожайности рассчитывали как отношение максимальной урожайности к средней в процентном выражении. Критерий приспособленности (Ко) определяли согласно методике, суть которой заключается в подсчете усредненных показателей продуктивности растений и ее структурных компонентов. Зимостойкость изучаемых сортообразцов варьировала от 89,5 до 96,7 \% в условиях Среднего Поволжья и от 92,3 до 96,9\% в Крыму. Были выявлены образцы с высокой (выше $98 \%)$, средней (90-95\%) и низкой (ниже $90 \%$ ) зимостойкостью. Самая высокая зимостойкость отмечена у сорта Барон и линии и.о.-4156, которые превосходили стандартный сорт Пензяк на 0,8-1,0 \%. Урожайность изученных сортов и сортообразцов изменялась в зависимости от региона возделывания, однако образцы Дикий и и.о.3290 были значительно эффективнее контроля: их продуктивность в условиях Средневолжского региона составила 1,85 и 1,97 т/га, в Крыму - 1,73 и 1,83 т/га. Наиболее масличными оказались сорта Барон и Козырь - соответственно 43,90 и 43,60\%. Потенциал урожайности по обеим регионам возделывания был сравнительно высоким и составил 70,9-88,9\% в Среднем Поволжье и 71,1-86,3\% в степном Крыму, а наибольшее значение он имел у сортообразца Дикий (соответственно 86,3 и 88,9 \%). Самым высоким критерием приспособленности Ко характеризовались об-

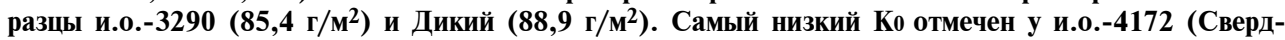
ловск) и и.о.-4175 (Чехословакия) - соответственно 56,3 и 59,6 г/м². Высокая адаптивность сортообразцов Дикий $(\mathrm{bi}=\mathbf{0 , 9 8 - 0 , 9 9 )}$ и и.о.-3290 $(\mathrm{bi}=\mathbf{0 , 9 6 - 0 , 9 5 )}$ позволяет возделывать их как в условиях Среднего Поволжья, так и в степном Крыму. Низкую адаптивность отмечали у и.о.-2219 $(b i=0,89)$ в Пензенском регионе, в то время как в условиях Крыма у этого образца bi = 1,15.

Ключевые слова: рыжик озимый, продуктивность, регион возделывания, Средняя Волга, Крым, масличность.

В процессе роста и развития растения испытывают негативное воздействие факторов внешней среды, к которым относятся температурные колебания и избыточное или недостаточное увлажнение. Каждое растение обладает генотипической способностью к адаптации в меняющихся условиях среды обитания. Согласно А.А. Жученко, адаптивность растений и эколо- 
гическая устойчивость к неблагоприятным факторам служат основополагающими критериями в адаптивной селекции. При этом приспособленность новых сортов к конкретным почвенно-климатическим условиям характеризует их агроэкологическую адресность (1).

Рыжик озимый (Camelina sylvestris Waller ssp. pilosa Zing.) - масличная культура, которая становится все более востребованной благодаря высокой масличности и широким возможностям использования $(2,3)$. Потенциальная урожайность семян рыжика составляет больше 2,0 т/га, а содержание масла в них выше 40 \% $(4,5)$. Обладая хорошими вкусовыми качествами, рыжиковое масло непосредственно используется в пищу, но также перерабатывается для приготовления олифы, синтетических липидов, зеленого мыла и других технических продуктов (6-8), находит применение в косметике, ароматерапии и медицине $(9,10)$. Кроме того, перспективно использование рыжика для получения биодизеля и биоавиакеросина, имеющих отличные физико-химические характеристики и эксплуатационные параметры (10-12).

Уникальность рыжика озимого состоит в его малой требовательности к условиям выращивания, поскольку он имеет высокую степень адаптации (14-16). С экологической точки зрения рыжик озимый - довольно пластичное растение, легко приспосабливающееся к различным почвенноклиматическим условиям $(17,18)$. Отличительные черты рыжика - высокая зимостойкость (19), раннее созревание и засухоустойчивость $(20,21)$.

По данным ФАО (Food and Agriculture Organization, FAO), рыжик озимый в настоящее время возделывается в ряде регионов Российской Федерации на площади 142 тыс. га (22). Однако для Крыма это новая культура, изучение которой началось с 2015 года.

Увеличение посевных площадей рыжика озимого и повышение его продуктивности зависят от генетического разнообразия сортов и сортообразцов, адаптированных к местным условиям, а также от взаимодействия генотип-среда $(23,24)$. Современные методы в селекции сельскохозяйственных культур, в том числе масличных, направлены не только на увеличение продуктивности и качества семян, но и на наращивание потенциала адаптивных возможностей генотипа при воздействии биотических и абиотических факторов среды $(25,26)$. При внедрении в производство новых высокопродуктивных сортов озимого рыжика скрининг на адаптивность и стабильность считается одним из важных этапов их оценки.

В представленной работе на основании результатов многолетних исследований впервые установлено, что в условиях Среднего Поволжья и степного Крыма изученные сортообразцы озимого рыжика проявляют адаптивность, стабильность и способность формировать высокий и качественный урожай. Это позволяет использовать их для селекции новых сортов, адаптированных к возделыванию в обоих регионах

Нашей целью была оценка сортообразцов озимого рыжика по экологической адаптивности и стабильности в контрастных агроэкологических условиях.

Методика. Исследования проводили в 2015-2017 годах в двух агроэкологических регионах, контрастных по климатическим условиям, - Среднем Поволжье (Пензенский НИИ сельского хозяйства, р.П. Лунино, Пензенская обл.) и степном Крыму (НИИ сельского хозяйства Крыма, с. Клепинино, Красногвардейский р-н) на сортах Пензяк, Козырь, Барон и сортообразцах Дикий, и.о.-4172, и.о.-1357, и.о.-2219, и.о.-4155, и.о.-4164, и.о.4156, и.о.-4175, и.о.-3290, и.о.-4165 рыжика озимого различного экологогеографического происхождения. Стандартом служил сорт Пензяк (селекция 
Пензенского НИИ сельского хозяйства).

Почва опытного участка Пензенского НИИСХ - чернозем выщелоченный с содержанием гумуса в пахотном слое $6,4 \%$, азота, фосфора и калия соответственно 81,3; 136,7 и 164,9 мг/кг, pH 5,5. Почва экспериментального участка НИИСХ Крыма - чернозем южный слабогумусированный с содержанием гумуса 2,4-2,6 \%, азота, фосфора и калия соответственно 2,2; 4,5 и 39,0 мг/кг, $\mathrm{pH} 7,3$.

В 2009 году в Пензенском НИИСХ методом индивидуального отбора из коллекционных сортообразцов рыжика был создан исходный материал для селекции. В 2014 году выделенные линии были переданы для экологического испытания в НИИСХ Крыма.

Возделывание рыжика в севообороте, закладку полевых опытов, наблюдения и учеты осуществляли по рекомендациям для масличных культур (27). Посев проводили в оптимальные для конкретного региона сроки рядовым способом с междурядьями 15 см и нормой высева семян 8,0 млн шт/га. Зимостойкость сортов и сортообразцов оценивали на основании данных осеннего и весеннего учетов состояния посевов в каждом повторении по обеим зонам. Урожайность определяли методом пробных площадок $\left(1 \mathrm{M}^{2}\right)$.

Статистическую обработку данных выполняли по Б.А. Доспехову (28) с использованием пакета программ Microsoft Excel 2010 и Statistica 8 («StatSoft, Inc.», США). Определяли средние значения (M) и их стандартные ошибки ( $\pm \mathrm{SEM})$. Достоверность различий между вариантами оценивали методами параметрической статистики ( $t$-критерий Стьюдента). Параметры экологической стабильности и адаптивности $\left(\mathrm{b}_{\mathrm{i}}\right)$ определяли по методике А.В. Кильчевского и Л.В. Хотылевой (29) на основании коэффициента регрессии. Реализацию потенциала урожайности рассчитывали, как отношение максимальной урожайности к средней в процентном выражении, основываясь на методике Э.Д. Неттевича (30). Критерий приспособленности $\left(\mathrm{K}_{0}\right)$ определяли согласно методике, описанной О.А. Беленкевичем, которая основывается на подсчете усредненных показателей продуктивности растений и ее структурных компонентов (31).

Результаты. Климат Средневолжского региона умеренно-континентальный с суммой годовых осадков от 350 до 750 мм. В годы исследований климатические условия вегетации рыжика различались по степени увлажнения: 2016 год характеризовался как засушливый (гидротермический коэффициент ГТК - 0,74), 2015 год был сильно увлажненным (ГТК - 1,37). Оптимальным по влагообеспеченности оказался 2017 год (ГТК - 1,10).

Опытно-исследовательский участок НИИСХ Крыма относится к зоне степного Крыма, климат которого характеризуется как континентальный, сумма осадков в год составляет в среднем 428 мм. В среднем за годы проведения исследований за период вегетации рыжика озимого выпало от 334,7 до 606,9 мм. Наиболее засушливым был 2017 год (ГТК - 0,61), 2016 год характеризовался как недостаточно увлажненный (ГТК $-0,82)$, оптимальным по влагообеспеченности был 2015 год $($ ГТК $-1,11)$.

Зимостойкость - важный биологический признак, определяющий способность растений противостоять низким температурам и иным стрессорам в зимний и ранневесенний период. Рыжик отличается от других озимых капустных культур (например, рапса и сурепицы) высокой морозо- и зимостойкостью $(18,20)$. В условиях Пензенского НИИСХ зимостойкость сортообразцов озимого рыжика колебалась от 89,5 до 96,7 \%. При этом были выделены образцы с высокой (95,3-96,7 \% - Козырь, Барон, и.о.4164, и.о.-3290, и.о.-2219), средней (93,2-94,8 \% - Пензяк, Дикий, и.о.- 
4165, и.о.-1357, и.о.-4175) и низкой (89,5-89,9 \% - и.о.-4172, и.о.-4155, и.о.4156) зимостойкостью (табл. 1).

1. Зимостойкость сортов и сортообразцов рыжика озимого (Camelina sylvestris Waller ssp. pilosa Zing.) в зависимости от региона возделывания (M $\pm \mathrm{SEM}$, 2015-2017 годы)

\begin{tabular}{|c|c|c|c|}
\hline \multirow[b]{2}{*}{$\begin{array}{l}\text { Сорт, } \\
\text { сортообразец }\end{array}$} & \multirow[b]{2}{*}{ Происхождение } & \multicolumn{2}{|c|}{ Регион возделывания } \\
\hline & & $\begin{array}{l}\text { Среднее Поволжье (р.П. Лу- } \\
\text { нино, Пензенская обл.) }\end{array}$ & $\begin{array}{l}\text { степной Крым (с. Клепинино, } \\
\text { Красногвардейский р-н) }\end{array}$ \\
\hline Пензяк (st) & Пенза & $94,8 \pm 0,98$ & $95,9 \pm 0,33$ \\
\hline Козырь & Пенза & $95,3 \pm 0,98$ & $95,6 \pm 0,33$ \\
\hline Барон & Пенза & $96,5 \pm 0,98$ & $96,7 \pm 0,33$ \\
\hline Дикий & Астрахань & $93,9 \pm 0,98$ & $93,3 \pm 0,33$ \\
\hline и.о. -4172 & Свердловск & $89,9 \pm 0,98$ & $93,9 \pm 0,33$ \\
\hline и.о.-1357 & Франция & $94,2 \pm 0,98$ & $92,3 \pm 0,33$ \\
\hline и.о.- -2219 & Украина & $95,9 \pm 0,98$ & $93,1 \pm 0,33$ \\
\hline и.о.- -4155 & Дагестан & $89,7 \pm 0,98$ & $92,9 \pm 0,33$ \\
\hline и.о.-4164 & Швеция & $96,3 \pm 0,98$ & $95,7 \pm 0,33$ \\
\hline и.о. -4156 & Республика Марий Эл & $89,5 \pm 0,98$ & $96,9 \pm 0,33$ \\
\hline и.о. -4175 & Чехословакия & $93,9 \pm 0,98$ & $96,3 \pm 0,33$ \\
\hline и.о.-3290 & Алтай & $96,7 \pm 0,98$ & $95,0 \pm 0,33$ \\
\hline и.о. -4165 & Германия & $93,2 \pm 0,98$ & $94,2 \pm 0,33$ \\
\hline $\mathrm{HCP}_{05}$ & & 1,08 & 0,99 \\
\hline
\end{tabular}

В Крыму устойчивость сортообразцов рыжика к условиям перезимовки была достаточно высокой (92,3-96,9 \%). Наибольший показатель отмечали у сорта Барон и селекционной линии и.о.-4156, которые превосходили сорт-стандарт соответственно на 0,8 и $1,0 \%$.

Урожайность изученных сортов и сортообразцов изменялась в зависимости от региона возделывания. Однако образцы Дикий и и.о.-3290 были значительно эффективнее контроля: их продуктивность в Средневолжском регионе составила 1,85 и 1,97 т/га, в Крыму - 1,73 и 1,83 т/га (табл. 2), что свидетельствует о наибольшем проявлении адаптивности, пластичности и стабильности этих сортообразцов при действии стрессовых факторов. Кроме того, в условиях степного Крыма по урожайности выделилась линия и.о.-1357 (Франция): превышение над контролем составило 0,10 т/га.

2. Урожайность и масличность сортов и сортообразцов рыжика озимого (Camelina sylvestris Waller ssp. pilosa Zing.) в зависимости от региона возделывания ( $M \pm$ SEM, 2015-2017 годы)

\begin{tabular}{|c|c|c|c|c|c|}
\hline \multirow{2}{*}{$\begin{array}{l}\text { Сорт, } \\
\text { сортообразец }\end{array}$} & \multirow{2}{*}{ Происхождение } & \multicolumn{2}{|c|}{$\begin{array}{l}\text { Среднее Поволжье (р.п. Лу- } \\
\text { нино, Пензенская обл.) }\end{array}$} & \multicolumn{2}{|c|}{$\begin{array}{l}\text { Степной Крым (с. Клепинино, } \\
\text { Красногвардейский р-н) }\end{array}$} \\
\hline & & $\begin{array}{l}\text { урожайность, } \\
\text { т/га }\end{array}$ & $\begin{array}{l}\text { масличность, } \\
\%\end{array}$ & $\begin{array}{l}\text { урожайность, } \\
\text { т/га }\end{array}$ & $\begin{array}{l}\text { масличность, } \\
\%\end{array}$ \\
\hline Пензяк (st) & Пенза & $1,65 \pm 0,08$ & $38,74 \pm 0,98$ & $1,64 \pm 0,03$ & $41,25 \pm 1,08$ \\
\hline Козырь & Пенза & $1,79 \pm 0,07$ & $39,66 \pm 0,98$ & $1,66 \pm 0,02$ & $43,50 \pm 1,08$ \\
\hline Барон & Пенза & $1,86 \pm 0,05$ & $40,46 \pm 0,88$ & $1,59 \pm 0,02$ & $43,90 \pm 1,08$ \\
\hline Дикий & Астрахань & $1,97 \pm 0,08$ & $40,19 \pm 1,02$ & $1,83 \pm 0,02$ & $38,19 \pm 1,10$ \\
\hline и.о. -4172 & Свердловск & $1,57 \pm 0,07$ & $38,53 \pm 1,01$ & $1,54 \pm 0,03$ & $36,71 \pm 1,08$ \\
\hline и.о.-1357 & Франция & $1,69 \pm 0,08$ & $38,69 \pm 0,98$ & $1,74 \pm 0,03$ & $38,03 \pm 1,09$ \\
\hline и.о.-2219 & Украина & $1,81 \pm 0,09$ & $37,42 \pm 0,88$ & $1,57 \pm 0,03$ & $35,61 \pm 0,98$ \\
\hline и.о. -4155 & Дагестан & $1,76 \pm 0,07$ & $38,41 \pm 0,88$ & $1,66 \pm 0,02$ & $37,79 \pm 0,99$ \\
\hline и.о.-4164 & Швеция & $1,64 \pm 0,08$ & $37,96 \pm 0,98$ & $1,67 \pm 0,02$ & $38,70 \pm 1,01$ \\
\hline и.о. -4156 & Республика Марий Эл & $1,72 \pm 0,09$ & $37,38 \pm 0,98$ & $1,69 \pm 0,02$ & $38,37 \pm 0,99$ \\
\hline и.о.- -4175 & Чехословакия & $1,61 \pm 0,09$ & $37,79 \pm 0,98$ & $1,56 \pm 0,03$ & $36,95 \pm 1,08$ \\
\hline и.о.-3290 & Алтай & $1,85 \pm 0,09$ & $39,58 \pm 0,88$ & $1,73 \pm 0,02$ & $38,29 \pm 1,08$ \\
\hline и.о. -4165 & Германия & $1,72 \pm 0,08$ & $38,83 \pm 0,88$ & $1,67 \pm 0,02$ & $38,27 \pm 1,08$ \\
\hline $\mathrm{HCP}_{05}$ & & 0,12 & 1,03 & 0,04 & 1,12 \\
\hline и ме & Станда & нзяк; & & & \\
\hline
\end{tabular}

Содержание масла в семенах варьировало от 35,61 до 43,90\%. Наиболее масличными оказались сорта Барон и Козырь - соответственно 43,90 и 43,60 \%. Можно сказать, что они обладали экологической пластичностью при испытании в различных агроклиматических условиях. В 
Пензенской области следует отметить и.о.-2219 (Украина), урожайность которого составила $1,81 \mathrm{~T} / г а$, что превышало показатель у сорта-стандарта Пензяк на 0,16 т/га.

Реализация потенциала урожайности сортов и сортообразцов озимого рыжика как в условиях лесостепной зоны Среднего Поволжья, так и в степной зоне Крыма была в целом сравнима и составляла соответственно 70,9-88,9 и 71,1-86,3 \%. Наиболее полно свои возможности использовали сортообразцы и.о.-3290 и Дикий - 82,5-84,9 и 86,3-88,9 \%, что можно объяснить их большей способностью противостоять действию абиотических стрессов (рис. 1).

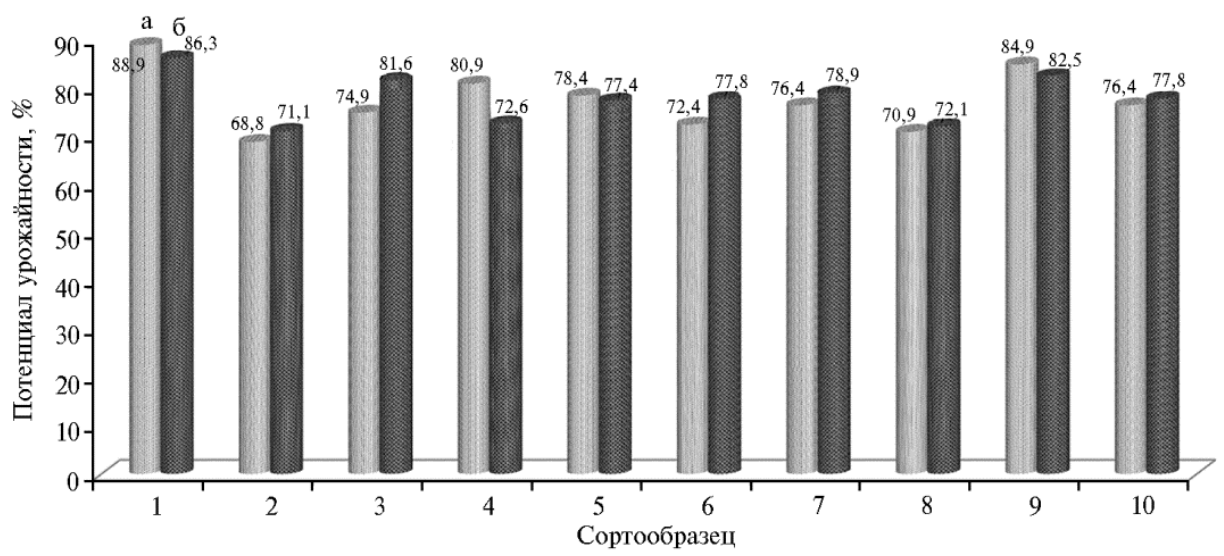

Рис. 1. Реализация потенциала урожайности сортообразцов озимого рыжика (Camelina sylvestris Waller ssp. pilosa Zing.) в условиях Среднего Поволжья (р.П. Лунино, Пензенская обл.) (а) и степного Крыма (с. Клепинино, Красногвардейский р-н) (б): 1 - Дикий, 2 - и.о.-4172, 3 и.о.-1357, 4 - и.о.-2219, 5 - и.о.-4155, 6 - и.о. $-4164,7$ - и.о.-4156, 8 - и.о. $-4175,9$ - и.о.3290, 10 - и.о.-4165 (2015-2017 годы).

Наиболее стабильными и пластичными как в условиях Среднего Поволжья, так и степного Крыма были сортообразцы Дикий $\left(b_{i}=0,98-0,99\right)$ и и.о.-3290 ( $\left.b_{i}=0,96-0,95\right)$, которые оказались более адаптированы к различным, в том числе неблагоприятным, условиям вегетации (рис. 2). Сортообразцы, у которых коэффициент стабильности $b_{i}>1,0$, относятся к интенсивному типу, хорошо отзываются на улучшение агротехнологических условий, но чаще снижают свою продуктивность при стрессовых агроклиматических факторах $(22,23)$.

Продуктивность культуры зависит от элементов структуры урожая, доля вклада которых в конечную урожайность обусловлена влиянием факторов генотипа и среды (24) и оценивается по критерию приспособленности $\left(\mathrm{K}_{0}\right)$ к условиям возделывания (31). В наших опытах в среднем по обоим регионам исследования наиболее высоким критерием приспособленности

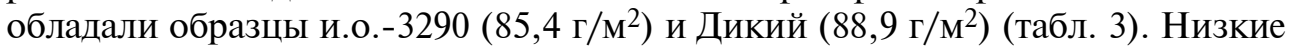
значения К К были отмечены у сортообразцов и.о.-4172 (Свердловск) и и.о.-

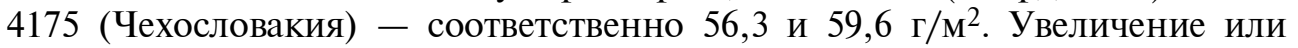
уменьшение $\mathrm{K}_{0}$ у образцов рыжика происходило в результате изменения соотношений размера вкладов основных компонентов в конечную урожайность семян.

Все сортообразцы имели положительные значения $\mathrm{K}_{0}$, что было обусловлено в основном компенсаторными эффектами за счет увеличения числа стручков на растении, числа семян в стручке и массы 1000 семян. При отрицательном значении одного из показателей положительные критерии перекрывались плюсовыми эффектами по другим компонентам урожайности семян. Это объясняет неодинаковую реакцию сортообразцов на 
климатические факторы в течение периода вегетации и их адаптивность и приспособленность к регионам возделывания.

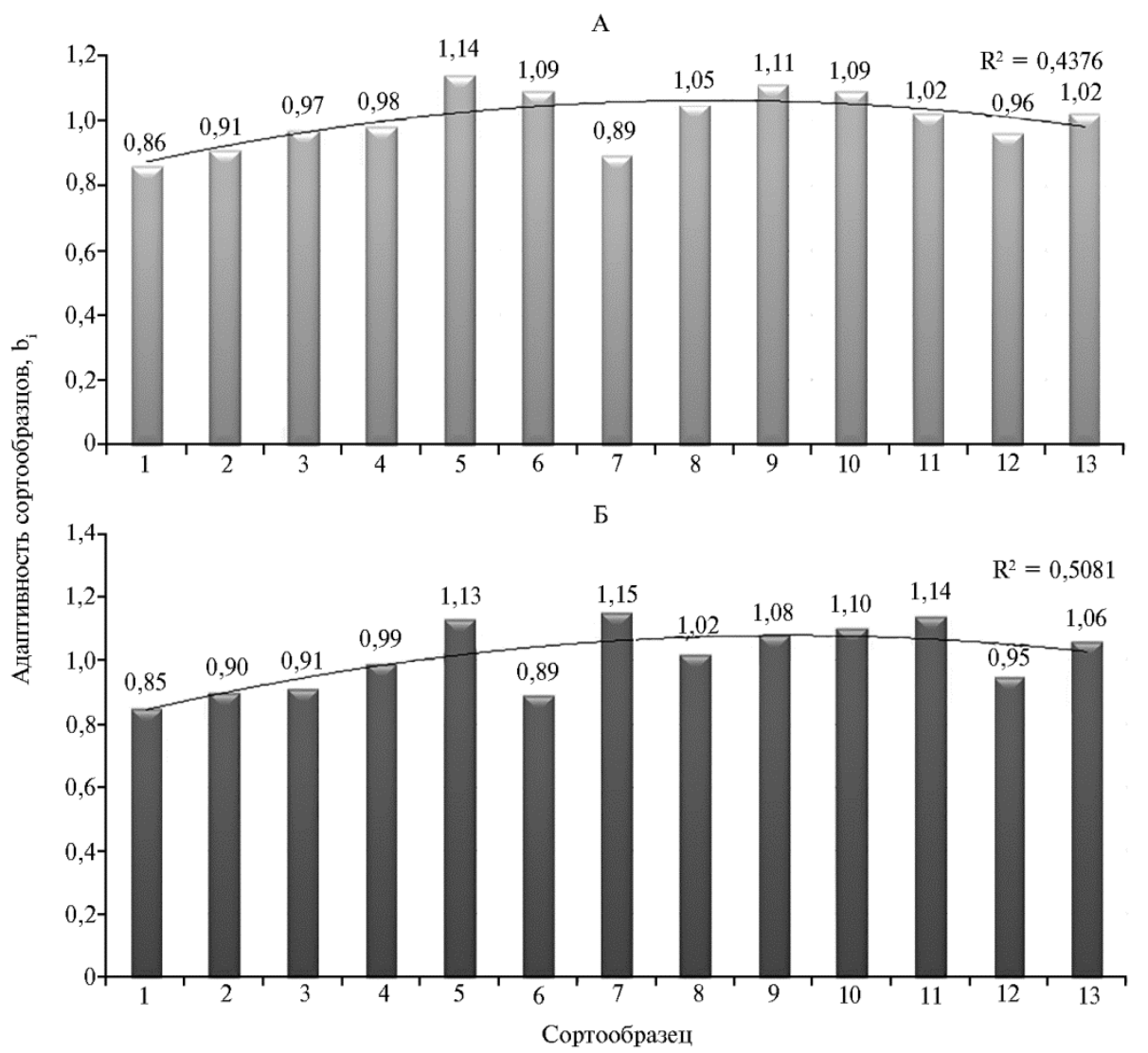

Рис. 2. Экологическая адаптивность сортов и сортообразцов озимого рыжика (Camelina sylvestris Waller ssp. pilosa Zing.) в условиях Среднего Поволжья (р.п. Лунино, Пензенская обл.) (А) и степного Крыма (с. Клепинино, Красногвардейский р-н) (Б): 1 - сорт Пензяк (стандарт, st), 2 - сорт Козырь, 3 - сорт Барон, 4 - Дикий, 5 - и.о.-4172, 6 - и.о.-1357, 74 - и.о.-2219, 8 и.о.-4155, 9 - и.о.-4164, 10 - и.о.-4156, 11 - и.о.-4175, 12 - и.о.-3290, 13 - и.о.-4165 (20152017 годы).

3. Оценка критерия приспособленности $\left(\mathrm{K}_{0}\right)$ сортообразцов озимого рыжика (Camelina sylvestris Waller ssp. pilosa Zing.) в условиях Среднего Поволжья (р.п. Лунино, Пензенская обл.) и степного Крыма (с. Клепинино, Красногвардейский р-н) (в среднем по регионам за 2015-2017 годы)

\begin{tabular}{|c|c|c|c|c|}
\hline \multirow{2}{*}{$\begin{array}{l}\text { Сорт, } \\
\text { сортообразец }\end{array}$} & \multirow{2}{*}{$\begin{array}{l}\text { Общий критерий } \\
\text { приспособленности, г/м² }\end{array}$} & \multicolumn{3}{|c|}{ Доля вклада элементов структуры урожая в $\mathrm{K} 0, \%$} \\
\hline & & $\begin{array}{l}\text { число стручков, } \\
\text { шт. }\end{array}$ & $\begin{array}{l}\text { число семян } \\
\text { в стручке, шт. }\end{array}$ & масса 1000 семян, г \\
\hline Пензяк (st) & 83,7 & 78,6 & 28,8 & 14,2 \\
\hline Козырь & 84,1 & 81,2 & 33,1 & 15,2 \\
\hline Барон & 84,9 & 75,9 & 26,3 & 17,2 \\
\hline Дикий & 88,9 & 119,6 & $-30,7$ & 35,1 \\
\hline и.о. -4172 & 56,3 & 46,5 & $-21,6$ & 32,8 \\
\hline и.о.-1357 & 79,5 & 79,5 & 96,8 & $-47,3$ \\
\hline и.о.-2219 & 72,3 & 102,0 & 50,8 & 17,2 \\
\hline и.о. -4155 & 74,6 & 85,6 & $-43,1$ & 61,8 \\
\hline и.о. -4164 & 69,8 & 78,6 & 55,6 & $-40,9$ \\
\hline и.о.-4156 & 75,1 & 77,5 & $-27,7$ & 50,2 \\
\hline и.о. -4175 & 59,6 & 51,3 & $-28,3$ & $-33,9$ \\
\hline и.о.-3290 & 85,4 & 75,9 & 29,4 & 45,3 \\
\hline и.о.- -4165 & 71,9 & 66,3 & 50,3 & $-64,0$ \\
\hline
\end{tabular}

В настоящее время в связи с трансформацией климатических условий 
оценка адаптивности и стабильности культуры считается одним из важнейших этапов в селекционном процессе. К числу первых публикаций по оценке стабильности и адаптивности сортов озимого рыжика относится работа Т.Я. Праховой с соавт. (20), где были проанализированы сорта Пензяк, Козырь, Барон и Передовик в различных агроэкологических условиях Волгограда, Краснодара, Республики Крым и Пензенской области. Других подобных публикаций по культуре озимого рыжика нам найти не удалось. Однако известно большое количество аналогичных работ по другим культурам (в том числе в связи с проблемами экологически устойчивого земледелия) - по пшенице (32), ячменю (33), кукурузе (34), льну (24), рапсу (18).

О возможности выявления адаптивных и стабильных форм у льнадолгунца в условиях Беларуси сообщают К.П. Королев с соавт. (24). A. Diederichsen с соавт. (35) проводили такие исследования в условиях Всероссийского НИИ льна (г. Торжок). На основании анализа работ других авторов и проведенной оценки селекционного материала озимого рыжика нами был выделен ряд перспективных сортообразцов, которые по показателям адаптивности и стабильности превышают существующие сорта и способны формировать стабильные урожаи при ухудшении теплового и водного режимов.

Таким образом, в результате агроэкологической оценки озимого рыжика по основным параметрам продуктивности, стабильности и экологической пластичности в двух контрастных агроэкологических регионах были выделены сортообразцы, характеризующиеся высокой продуктивностью и устойчивостью к различным условиям возделывания. Наиболее стабильными и пластичными были сортообразцы Дикий (bi $=0,98-0,99)$ и и.о.-3290 (bi $=0,96-0,95)$, которые по продуктивности существенно превосходили сорт Пензяк в обоих регионах возделывания. Эти образцы имеют высокую селекционную ценность, их можно использовать для создания сортов с высокой стабильной продуктивностью и адаптивностью к контрастным условиям указанных регионов. Среди изученных сортообразцов и.о.-4155, и.о.4156 и и.о.-4165 отличались невысокой, но стабильной урожайностью по годам (1,66-1,76 т/га) и имели значение $b_{i}=1,02-1,10$, что показывает их отзывчивость на изменения условий возделывания.

\section{ЛИТЕРАТУРА}

1. Жученко А.А. Адаптивная система селекции растений (эколого-генетические основы). М., 2001: 529, 539.

2. Joshi S.K., Ahamada S., Meher L.C., Agarwal A., Nasim M. Growth and yield response of Camelina Sativa to inorganic fertilizers and farmyard manure in hot semi-arid climate of India. Adv. Plants Agric. Res., 2017, 7(3): 1-6 (doi: 10.15406/apar.2017.07.00258).

3. Ghamkhar K., Croser J., Aryamanesh N., Campbell M., Kon'kova N., Francis C. Camelina (Camelina sativa (L.) Crantz) as an alternative oilseed: molecular and ecogeographic analyses. Genome, 2010, 53(7): 558-567 (doi: 10.1139/G10-034).

4. Imbrea F., Jurcoane S., Hălmăjan H.V., Duda M., Botoş L. Camelina sativa: a new source of vegetal oils. Romanian Biotechnological Letters, 2011, 16(3): 6263-6270.

5. Katar D., Arslan Y., Subaşı İ., Tekirdağ Z., Fakültesi D. Ankara ekolojik koşullarında farklı ekim zamanlarının ketencik (Camelina sativa (L.) Crantz) bitkisinin yağ oranı ve bileşimi üzerine olan etkisinin belirlenmesi. Journal of Tekirdag Agricultural Faculty, 2012, 3: 84-90.

6. Waraich E.A., Ahmed Z., Ahmad R., Ashraf M.Y., Saifullah, Naeem M.S., Rengel Z. Camelina sativa, a climate proof crop, has high nutritive value and multiple-uses: a review. Australian Journal of Crop Science, 2013, 7(10): 1551-1559.

7. Moser B.R. Camelina (Camelina sativa L.) oil as biofueis feedstock: golden opportunity or false hope. Lipid technology, 2010, 22(12): 270-273 (doi: 10.1002/lite.201000068).

8. Зазуля Л.Н., Нагорнов С.А., Романцова С.В., Малахов К.С. Получение биодизельного топлива из растительных масел. Достижения науки и техники АПК, 2009, 12: 58-60.

9. Буянкин В.И. Масличный рыжик на юге России. Масла и жиры, 2008, 3: 19-22.

10. Dobre P., Jurcoane Ş. Camelina sativa - an oilseed crop with unique agronomic characteristics. In: Scientific Papers, Series A, Vol. LIV. Bucharest, 2011: 425-430. 
11. Sharma N. Assessment of biofuel potential in India. International Journal of Recent Scientific Research, 2017, 8: 17125-17127 (doi: 10.24327/ijrsr.2017.0805.0287).

12. Wu X., Leung D. Orthogonal array design for biodiesel production optimization - using ultrasonic-assisted transesterification of Camelina sativa L. Crantz oil. Proc. of the World Renewable Energy Congress. Linköping, Sweden, 2011, V. 57: 79-86 (doi: 10.3384/ecp1105779).

13. Сидоров Е.А., Уханов А.П., Зеленина О.Н. Оценка жирнокислотного состава растительных масел и дизельных смесевых топлив на основе рыжика, сурепицы и льна масличного. Известия Самарской государственной сельскохозяйственной академии, 2013, 3: 49-54.

14. Mohammed Y.A., Chen C., Lamb P.F., Afshar R.K. Agronomic evaluation of camelina (Camelina sativa (L.) Crantz) cultivars for biodiesel feedstock. BioEnergy Research, 2017, 10: 792-799 (doi: 10.1007/s12155-017-9840-9).

15. Vinovets V.G., Lisnyak A.D., Ivanov M.V. Selection estimation variety samples of yellow seeds spring rape. Науково-технічний бюлетень Інституту олійних культур НАAН, 2014, 20: 86-91.

16. Лошкомойников И.А., Кузнецова Г.Н. Технология возделывания ярового рыжика в Западной Сибири. Кормопроизводство, 2009, 4: 24-27.

17. Рябцева Н.А. Возможности возделывания Camelina sylvestris Waller в Ростовской области. Сельское, лесное и водное хозяйство, 2015, 1(40): 14-17.

18. Mostofa U.H., Nazrul I., Monjurul K., Noor H.M. Performance of rapeseed and mustard (Brassica sp.) varieties/lines in north-east region (Sylhet) of Bangladesh. Agricultural Research \& Technology, 2016, 1(5): 001-006 (doi: 10.19080/ARTOAJ.2016.02.555576).

19. Бекузарова С.А., Дулаев Т.А. Рыжик озимый - новая культура в Северной Осетии-Алания. Новые нетрадищионные растения и перспективы их использования, 2016, 12: 182-184.

20. Прахова Т.Я., Смирнов А.А., Прахов В.А., Турина Е.Л., Кулинич Р.А. Продуктивность рыжика озимого в зависимости от сроков сева в разных климатических регионах. Tруды Кубанского государственного аграрного университета, 2017, 66: 203-207 (doi: 10.21515/19991703-66-203-207).

21. Campbell M. Camelina - an alternative oil crop. In: Biokerosene. M. Kaltschmitt, U. Neuling (eds.). Springer, Berlin, Heidelberg, 2018: 259-275 (doi: 10.1007/978-3-662-53065-8_12).

22. FAO Data Dissemination. Режим доступа: http://www.fao.org/statistics/databases/ru/. Без даты.

23. Galasso I., Manca A., Braglia L., Ponzoni E., Breviario D. Genomic fingerprinting of Camelina species using c TBP as molecular marker. American Journal of Plant Sciences, 2015, 6(8): $1184-$ 1200 (doi: 10.4236/ajps.2015.68122).

24. Королев К.П., Боме Н.А. Оценка генотипов льна-долгунца (Linum usitatissimum L.) по экологической адаптивности и стабильности в условиях северо-восточной части Беларуси. Сельскохозяйственная биология, 2017, 3(52): 615-621 (doi: 10.15389/agrobiology.2017.3.615rus).

25. Кильчевский А.В. Генетико-экологические основы селекции растений. Вестник ВОГиС, 2005, 4(9): 518-526.

26. Betancor M.B., Li K., Bucerzan V.S., Sprague M., Sayanova O.V., Usher S.L., Han L., Norambuena F., Torrissen O.J., Napier J.A., Tocher D.R., Olsen R.E. Oil from transgenic Camelina sativa containing over $25 \% \mathrm{n}-3$ long-chain PUFA as the major lipid source in feed for Atlantic salmon (Salmo salar). British Journal of Nutrition, 2018, 119(12): 1378-1392 (doi: 10.1017/S0007114518001125).

27. Методика проведения полевых агротехнических опытов с масличными культурами /Под ред. В.М. Лукомца. Краснодар, 2010.

28. Доспехов Б.А. Методика полевого опыта с основами статистической обработки результатов исследований. М., 1985.

29. Кильчевский А.В., Хотылева Л.В. Генетические основы селекции растений. Общая генетика растений. Минск, 2008: 50-56.

30. Неттевич Э.Д. Потенциал урожайности рекомендованных для возделывания в Центральном районе РФ сортов яровой пшеницы и ячменя и его реализация в условиях производства. Доклады РАСХН, 2001, 3: 50-55.

31. Беленкевич О.А. Физиолого-генетические аспекты взаимосвязей между растениями ярового ячменя в моноценозе. Сельскохозяйственная биология, 2002, 3: 57-61.

32. Voss-Fels K.P., Stahl A., Wittkop B., Lichthardt C., Nagler S., Rose T., Chen T.W., Zetzsche H., Seddig S., Majid Baig M., Ballvora A., Frisch M., Ross E., Hayes B.J., Hayden M.J., Ordon F., Leon J., Kage H., Friedt W., Stützel H., Snowdon R.J. Breeding improves wheat productivity under contrasting agrochemical input levels. Nat. Plants, 2019, 5(7): 706-714 (doi: 10.1038/s41477-0190445-5).

33. Ceccarelli S., Grando S., Capettini F., Baum M. Barley breeding for sustainable production. In: Breeding major food staples /M.S. Kang, P. Priyadarshan (eds). Blackwell Publishing, Oxford, 2008: 193-225 (doi: 10.1002/9780470376447.ch7).

34. Reeves T.G., Thomas G., Ramsay G. Save and grow in practice. Maize, rice, wheat. A guide to sustainable cereal production. FAO, Rome, 2016.

35. Diederichsen A., Rozhmina L., Kudrjavceva A. Variation patterns within 153 flax (Linum usitatissimum L.) genebank accessions based on evaluation for resistance to fusarium wilt, anthracnose and pasmo. Plant Genetic Resources, 2008, 6: 22-32 (doi: 10.1017/S1479262108913897). 


\section{2ФГБНУ Федеральный научный центр лубяных культур,}

442731 Россия, Пензенская обл., Лунино-1, ул. Мичурина, 1б,

e-mail: prakhova.tanya@yandex.ru, t.prakhova.pnz@fnclk.ru

\section{EVALUATION OF WINTER CAMELINA (Camelina sylvestris Waller ssp. pilosa Zing.) CULTIVARS FOR ENVIRONMENTAL ADAPTABILITY}

\section{E.L. Turina', T.Ya. Prakhova ${ }^{2}$, E.N. Turin'1, A.A. Zubochenco' ${ }^{1}$, V.A. Prakhov ${ }^{2}$}

${ }^{1}$ Research Institute of Agriculture of Crimea, 150, ul. Kievskaya, Simferopol, Republic of Crimea, Russia 295493, e-mail turina_e@niishk.ru, schigortsovaelena@rambler.ru ( $₫$ corresponding author), turin_e@niishk.ru, zubochenko_a@niishk.ru;

${ }^{2}$ Federal Research Center for Bast Fiber Crops, 1b, ul. Michurina, Lunino-1, Penza Province, Russia 442731, e-mail prakhova.tanya@yandex.ru, t.prakhova.pnz@fnclk.ru

ORCID:

Turina E.L. orcid.org/0000-0002-7791-3030

Prakhova T.Ya. orcid.org/0000-0002-7063-4784

Turin E.N. orcid.org/0000-0003-1680-2828

The authors declare no conflict of interests

Received August 18, 2019

Zubochenco A.A. orcid.org/0000-0003-3393-9885

Prakhov V.A. orcid.org/0000-0002-5469-5114

doi: 10.15389/agrobiology.2020.3.564eng

\section{Abstract}

Winter camelina (Camelina sylvestris Waller ssp. pilosa Zing.) is a promising oilseed crop that enjoys great popularity in the world because of high oil content and a wide range of uses. From the environmental point of view, winter camelina possesses phenotypic plasticity and seems to be particularly adapted to a wide range of soil and climatic conditions. Camelina is a cold-resistant and droughttolerant plant. Spread of winter camelina cultivation and its productivity improvement depends on the genetic diversity of cultivars adapted to the conditions of the region of its cultivation, as well as on the genotype-environment interaction. In the presented work, it was first established that in the conditions of the Middle Volga and Steppe Crimea, winter camelina specimens are adaptable, stable and able to produce high yield of good quality. This allows us to involve these forms in breeding new varieties adapted for cultivation in both regions. The aim of the work is to evaluate the cultivars of winter camelina for environmental adaptability and stability in two contrasting agroecological regions, the Middle Volga Region (Penza Agricultural Research Institute) and the steppe zone of the Crimea (Research Institute of Agriculture of Crimea) in 2015-2017. Varieties of Camelina sylvestris of various ecogeographical origins were investigated. Cultivar Penzyak (Penza Agricultural Research Institute) served as a standard. This cultivar has been cultivated in the Crimea on an industrial scale since 2015. Winter hardiness of the studied cultivars in the fields of Penza was high and ranged between $89.5 \%$ to $96.7 \%$, in the Crimean Peninsula territory it was $92.3-96.9 \%$. Various hardiness groups were identified: samples with high cold tolerance (more than $98 \%$ ), samples with the middle level of winter hardiness (90-95\%), and samples with low winter-tolerance (less than $90 \%$ ). Winter hardiness of the same samples varied within the range of 92.3-96.9\% under the Crimean environment. The highest level of winter hardiness was noted for the cultivar Baron and individual selection line 4156, which exceeded standard cultivar Penzyak by $0.8-1.0 \%$, respectively. The productivity of varieties in the Crimea was $1.64-1.83 \mathrm{t} / \mathrm{ha}$. Seed oil content varied from 35.61 to $43.90 \%$. The highest content of fat in seeds was noted in varieties Baron and Kozyr (43.90 and $43.60 \%$ ). Realization of yield potential of winter camelina cultivars and samples in the forest-steppe zone of the Middle Volga and steppe zone of the Crimea was relatively high, 70.9-88.9\% and 71.1-86.3\%, respectively. The highest level of yield realization was identified for the cultivar Dikiy $(86.3 \%$ and $88.9 \%)$. Two samples (Dikiy and individual selection line 3290) were the most effective in terms of productivity. Their productivity was $1.83-1.97$ when cultivated in Penza Agricultural Research Institute, and 1.73-1.85 t/ha in Research Institute of Agriculture of Crimea. On average, cultivar Dikiy $\left(88.9 \mathrm{~g} / \mathrm{m}^{2}\right)$ and individual selection line 3290 $\left(85.4 \mathrm{~g} / \mathrm{m}^{2}\right)$ showed the highest level of adaptability to the conditions of both territories. The lowest adaptability criterion was identified for the individual selection line 4172 from Sverdlovsk and individual selection line 4175 from Czechoslovakia, the fitness coefficients amounted 56.3 and $59.6 \mathrm{~g} / \mathrm{m}^{2}$, respectively. High adaptability of the samples $\left(b_{i}=0.98-0.99\right.$ for Dikiy and $b i=0.96-0.95$ for individual selection line 3290) allows their cultivation both in the Middle Volga and in Steppe Crimea. Low adaptability was noted for the individual selection line $2219(\mathrm{bi}=0.89)$ in the Penza region; in the Crimea, for the aforementioned individual selection line bi was 1.15 .

Keywords: winter camelina, productivity, cultivation, region, Middle Volga, Crimea, oil content. 